\title{
Risk Factors and Preventive Health Behavior among Hypertensive Clients Attending Master Health Checkup at Selected Hospitals, in Different Geographic Areas
}

\author{
Lalou L*, Sonia L and Venkatasan L
}

Apollo College of Nursing, Chennai, India

\begin{abstract}
Background: In this $21^{\text {st }}$ century, millions of people are affected with hypertension compared with the past

Aim: The study was aimed to assess the risk factors and preventive health behavior among hypertensive clients.

Methods: A cross sectional correlational study was carried out on 300 hypertensive clients attending master health checkup at selected hospitals in Tamil Nadu and Kerala using purposive sampling technique with checklist on risk factors of hypertension, structured interview schedule on knowledge questionnaire of hypertension and hypertension self-care behavior profile (HTN-SCBP) to assess the practice. The inclusion criteria were clients with hypertension with baseline systolic blood pressure equal to or above $120 \mathrm{mmHg}$ or diastolic blood pressure $>80 \mathrm{mmHg}$ or both, Exclusion criteria were hypertensive clients refused to participate in the study.

Results: There was no history of comorbid illness found in Tamil Nadu $33.33 \%$ whereas in Kerala $33.33 \%$ had cardiovascular disease and diabetes. In Tamil Nadu $27.33 \%$ of clients and $27.33 \%$ of clients in Kerala were obese. Occasional intake of salted, fried, oily foods found to be significant risk factors in Tamil Nadu and Kerala respectively. There was a statistically significant association and positive correlation between preventive health behavior and demographic and bio physiological variables. Hypertensive clients in Tamil Nadu (62.67\%) had moderately adequate knowledge and in Kerala (53.33\%) had adequate knowledge. Clients in Tamil Nadu (91.33\%) and Kerala followed good practices $(74 \%)$ regarding preventive health behavior of hypertension.
\end{abstract}

Conclusion: The researcher concludes that to find out the risk factors and preventive health behavior among hypertensive clients in Tamil Nadu and Kerala.

Keywords: Risk factors; Preventive health behavior; Hypertensive clients

\section{Introduction}

Hypertension is related to increased morbidity and mortality from cardiovascular, cerebrovascular, and renal vascular complications. The American Heart Association (2017) has defined ranges of blood pressure which are abnormal and those that indicate hypertension. An elevated blood pressure refers to systolic blood pressure $>120 \mathrm{mmHg}$ or diastolic blood pressure $>80 \mathrm{~mm} \mathrm{Hg}$ or both. Worldwide, raised blood pressure is estimated to cause 7.5 million deaths, about $12.8 \%$ of the total deaths. Globally, the overall prevalence of raised blood pressure in adults aged 25 and over was around $40 \%$ in 2008 and is predicted to increase to 1.56 billion by 2025 (WHO, 2016) [1].

\section{Statement of the Problem}

A Cross sectional Study to assess the Risk Factors and Preventive Health Behavior among Hypertensive Clients attending Master Health Check Up at Selected Hospitals, in Different Geographic Areas.

\section{Objectives}

1. To assess the risk factors of hypertension among hypertensive clients.

2. To assess the level of knowledge and practice regarding the preventive health behavior among hypertensive clients.

3. To find out the association between selected demographic variables and preventive health behavior among hypertensive clients.

4. To find out the association between selected bio physiological variables and preventive health behavior among hypertensive clients.

5. To find out the correlation between knowledge and practice regarding preventive health behavior among hypertensive clients.

\section{Hypotheses}

H01: There will be no significant association between the demographic variables and knowledge and practice regarding the preventive health behavior among hypertensive clients.

H02: There will be no significant association between the bio physiological variables and knowledge and practice regarding the preventive health behavior among hypertensive clients.

H03: There will be no significant relationship between knowledge and practice regarding the preventive health behavior among hypertensive clients.

*Corresponding author: Lijiya Lalou, Medical Surgical (Sub Speciality: Critical Care Nursing), Kezhakaripur House Vallamkulam, Pathanamthitta, Thiruvalla, Kerala, India, Tel: +918848872882; E-mail: lijiyastar@gmail.com

Received November 05, 2018; Accepted November 09, 2018; Published November 20, 2018

Citation: Lalou L, Sonia L, Venkatasan L (2018) Risk Factors and Preventive Health Behavior among Hypertensive Clients Attending Master Health Checkup at Selected Hospitals, in Different Geographic Areas. J Hypertens (Los Angel) 7: 256 doi: 10.4172/2167-1095.1000256

Copyright: $\odot 2018$ Lalou L, et al. This is an open-access article distributed unde the terms of the Creative Commons Attribution License, which permits unrestricted use, distribution, and reproduction in any medium, provided the original author and source are credited. 
Citation: Lalou L, Sonia L, Venkatasan L (2018) Risk Factors and Preventive Health Behavior among Hypertensive Clients Attending Master Health Checkup at Selected Hospitals, in Different Geographic Areas. J Hypertens (Los Angel) 7: 256. doi: 10.4172/2167-1095.1000256

Page 2 of 6

\section{Materials and Methods}

A cross sectional correlational study was conducted among 300 hypertensive clients selected using purposive sampling technique, from Apollo hospitals, Chennai, Tamil Nadu and Tiruvalla Medical Mission hospital, Kerala.

The data was collected using Demographic variable proforma, biophysiological variable proforma, check list on risk factors of hypertension was used. Structured interview schedule on knowledge questionnaire of hypertension was prepared by the researcher to assess the knowledge, Hypertension self-care behavior profile (HTN-SCBP) to assess the practice. There are 30 items with responses given on 4 point multiple choice questions. The questions were classified based on 5 dimensions that include hypertension and risk factors, signs and symptoms, diagnostic measures, management and preventive measures and complications of hypertension. The maximum score is 30 and the minimum score is 15 . The reliability of the tool was tested using split half method ( $\mathrm{r}=0.8$ ). Hypertension Self Care Behavior Profile (HTN-SCBP) is a standardized tool. The scale has 20 items with 7 sub dimensions of dietary habits, physical activity, maintain weight, control stress, avoid tobacco and alcohol, visit doctor regularly and medication adherence. The maximum score is 80 and minimum score is 20 . The reliability of the tool was determined by the researcher using the internal consistency method ( $\mathrm{r}=0.93)$. Data analysis was done using statistical software package SPSS for windows version 22. Appropriate descriptive and inferential statistics were used to analyze the data.

\section{Results}

Among 300 hypertensive clients who participated in the study, there was no history of comorbid illness found in Tamil Nadu $33.33 \%$ whereas in Kerala $33.33 \%$ had cardiovascular disease and diabetes. Occasional intake of salted snacks, fried foods and oily foods found to be significant risk factors in Tamil Nadu and Kerala respectively. Majority of the clients in Tamil Nadu had $76 \%$ of daily intake of red meat, whereas $30.67 \%$ in Kerala had red meat consumption once in a week. In Kerala, $85.33 \%$ had regular intake of caffeinated drink when compared to $4.67 \%$ in Tamil Nadu as given in Table 1.

On analysis there was significant association between knowledge and gender $\left(\chi^{2}=7.24, \mathrm{p}<0.05\right)$, educational qualification $\left(\chi^{2}=21.24\right.$ $\mathrm{p}<0.05)$, personal habits $\left(\chi^{2}=14.43, \mathrm{p}<0.05\right)$ and dietary habits $\left(\chi^{2}=9.90\right.$ $\mathrm{p}=<0.01)$ as described in Table 2 . There was significant association between knowledge and Serum Sodium $\left(\chi^{2}=15.03, p<0.001\right)$ and Serum Potassium $\left(\chi^{2}=6.41, p<0.05\right)$ given in Table 3. There was significant association between practice and personal habits $\left(\chi^{2}=22.59, \mathrm{p}<0.001\right)$ described in Table 4 . There was significant association between practice and Fasting Blood Sugar $\left(\chi^{2}=12.88, p<0.05\right)$, High Density Lipoprotein $\left(\chi^{2}=9.06, \mathrm{p}<0.05\right)$, Serum Bicarbonate $\left(\chi^{2}=5.97, \mathrm{p}<0.05\right)$ and duration of illness $\left(\chi^{2}=13.44, \mathrm{p}<0.05\right)$ given in Table 5 .

Figure 1 depicts that, In Tamil Nadu $27.33 \%$ of clients and $27.33 \%$ of clients in Kerala were obese, whereas 34.67\% in Tamil Nadu and 36\% in Kerala were moderately obese.

Figure 2 depicts that majority of the clients in Tamil Nadu (76\%) and more than half of them in Kerala (58\%) had moderate stress.

\begin{tabular}{|c|c|c|c|c|}
\hline \multirow[t]{3}{*}{ Risk factors } & \multicolumn{2}{|c|}{ Tamil Nadu } & \multirow{2}{*}{$\begin{array}{c}\text { Kerala } \\
(n=150)\end{array}$} & \multirow[b]{3}{*}{$\%$} \\
\hline & $(n=150)$ & & & \\
\hline & (f) & $\%$ & (f) & \\
\hline \multicolumn{5}{|c|}{ Regular intake of salted snacks and fried foods } \\
\hline Daily & 14 & 9.33 & 10 & 6.67 \\
\hline 2-4 times a week & 29 & 19.33 & 23 & 15.33 \\
\hline 4-6 times a week & 25 & 16.67 & 24 & 16 \\
\hline Once a week & 15 & 10 & 34 & 22.67 \\
\hline Occasionally & 48 & 32 & 53 & 35.33 \\
\hline Never & 19 & 12.67 & 6 & 4 \\
\hline \multicolumn{5}{|c|}{ Regular intake of oily foods } \\
\hline Daily & 3 & 2 & 22 & 14.67 \\
\hline 2-4 times a week & 18 & 12 & 28 & 18.67 \\
\hline 4-6 times a week & 24 & 16 & 22 & 14.67 \\
\hline Once a week & 30 & 20 & 20 & 13.33 \\
\hline Occasionally & 40 & 26.67 & 48 & 32 \\
\hline Never & 35 & 23.33 & 10 & 6.67 \\
\hline \multicolumn{5}{|c|}{ Regular intake red meat } \\
\hline Daily & 114 & 76 & 8 & 5.33 \\
\hline 2-4 times a week & 17 & 11.33 & 20 & 13.33 \\
\hline 4-6 times a week & 7 & 4.67 & 24 & 16 \\
\hline Once a week & 6 & 4 & 46 & 30.67 \\
\hline Occasionally & 4 & 2.67 & 42 & 28 \\
\hline Never & 2 & 1.33 & 10 & 6.67 \\
\hline \multicolumn{5}{|c|}{ Regular intake of caffeinated drink } \\
\hline Daily & 7 & 4.67 & 128 & 85.33 \\
\hline 2-4 times a week & 7 & 4.67 & 9 & 6 \\
\hline 4-6 times a week & 7 & 4.67 & 5 & 3.33 \\
\hline Once a week & 14 & 9.33 & 1 & 0.67 \\
\hline Occasionally & 46 & 30.67 & 3 & 2 \\
\hline Never & 69 & 46 & 4 & 2.67 \\
\hline
\end{tabular}

Table 1: Frequency and percentage distribution of risk factors of hypertension among hypertensive clients. 
Citation: Lalou L, Sonia L, Venkatasan L (2018) Risk Factors and Preventive Health Behavior among Hypertensive Clients Attending Master Health Checkup at Selected Hospitals, in Different Geographic Areas. J Hypertens (Los Angel) 7: 256. doi: 10.4172/2167-1095.1000256

Page 3 of 6

\begin{tabular}{|c|c|c|c|c|c|c|c|}
\hline \multirow[b]{2}{*}{ Demographic Variables } & \multicolumn{2}{|c|}{ Inadequate $(\leq 50 \%)$} & \multicolumn{2}{|c|}{ Moderately adequate (51-75\%) } & \multicolumn{2}{|c|}{ Adequate (76-100\%) } & \multirow{2}{*}{$\begin{array}{c}\chi^{2} \\
p \text { value }\end{array}$} \\
\hline & (f) & $\%$ & (f) & $\%$ & (f) & $\%$ & \\
\hline \multicolumn{7}{|l|}{ Gender } & \multirow{3}{*}{$\begin{array}{l}\chi^{2}=7.24 \\
p=0.02\end{array}$} \\
\hline Female & 13 & 4.3 & 81 & 27.0 & 80 & 26.7 & \\
\hline Male & 5 & 1.7 & 78 & 26.0 & 43 & 14.3 & \\
\hline \multicolumn{7}{|l|}{ Educational qualification } & \multirow{7}{*}{$\begin{array}{c}\chi^{2}=21.24 \\
p=0.01\end{array}$} \\
\hline Illiterate & 2 & 0.7 & 2 & 0.7 & 0 & 0 & \\
\hline Primary education & 2 & 0.7 & 45 & 15.0 & 28 & 9.3 & \\
\hline Secondary education & 4 & 1.3 & 31 & 10.3 & 30 & 10.0 & \\
\hline Higher secondary & 3 & 1.0 & 38 & 12.7 & 26 & 8.3 & \\
\hline Graduate & 4 & 1.3 & 30 & 10.0 & 31 & 10.3 & \\
\hline Post graduate & 3 & 1.0 & 13 & 4.3 & 9 & 3.0 & \\
\hline \multicolumn{7}{|l|}{ Dietary habits } & \multirow{3}{*}{$\begin{array}{l}\chi^{2}=9.90 \\
p=0.01\end{array}$} \\
\hline Vegetarian & 2 & 0.7 & 36 & 12.0 & 11 & 3.7 & \\
\hline Non vegetarian & 16 & 5.3 & 123 & 41.0 & 112 & 37.3 & \\
\hline \multicolumn{7}{|l|}{ Personal habits } & \multirow{5}{*}{$\begin{array}{c}\chi^{2}=14.43 \\
p=0.02\end{array}$} \\
\hline Smoking & 1 & 0.3 & 11 & 3.7 & 15 & 5.0 & \\
\hline Alcohol consumption & 0 & 0 & 5 & 1.7 & 14 & 4.7 & \\
\hline Tobacco chewing & 2 & 0.7 & 8 & 2.7 & 4 & 1.3 & \\
\hline No Habits & 15 & 5.0 & 135 & 45 & 90 & 30.0 & \\
\hline
\end{tabular}

$\mathrm{p}<0.05, \mathrm{p}<0.01$, S: Significant, NS: Not Significant.

Table 2: Association of the level of knowledge regarding the preventive health behavior among hypertensive clients with their selected demographic variables.

\begin{tabular}{|c|c|c|c|c|c|c|c|}
\hline \multirow[t]{2}{*}{ Bio physiological variables } & \multicolumn{2}{|c|}{ Inadequat $(\leq 50 \%)$} & \multicolumn{2}{|c|}{ Moderately adequate (51-75\%) } & \multicolumn{2}{|c|}{ Adequate $(76-100 \%)$} & \multirow{2}{*}{$\begin{array}{c}\chi^{2} \\
\mathrm{p} \text { value }\end{array}$} \\
\hline & (f) & $\%$ & (f) & $\%$ & (f) & $\%$ & \\
\hline \multicolumn{7}{|l|}{ Serum sodium } & \multirow{3}{*}{$\begin{array}{l}\chi^{2}=15.03 \\
p=0.001\end{array}$} \\
\hline$<135 \mathrm{meq} / \mathrm{L}$ & 10 & 3.3 & 132 & 44.0 & 80 & 26.7 & \\
\hline$>145 \mathrm{meq} / \mathrm{L}$ & 8 & 2.7 & 27 & 9.0 & 43 & 14.3 & \\
\hline \multicolumn{7}{|l|}{ Serum potassium } & \multirow{3}{*}{$\begin{array}{l}\chi^{2}=6.41 \\
p=0.04\end{array}$} \\
\hline$<3.5 \mathrm{meq} / \mathrm{L}$ & 8 & 2.7 & 116 & 38.7 & 88 & 29.3 & \\
\hline$\geq 5.5 \mathrm{meq} / \mathrm{L}$ & 10 & 3.3 & 43 & 14.3 & 35 & 11.7 & \\
\hline
\end{tabular}

$\mathrm{p}<0.001, \mathrm{p}<0.05$, S: Significant, NS: Not Significant.

Table 3: Association of the level of knowledge regarding the preventive health behavior among hypertensive clients with their selected bio physiological variables.

\begin{tabular}{|c|c|c|c|c|c|c|c|}
\hline \multirow[t]{2}{*}{ Demographic variables } & \multicolumn{2}{|c|}{ Poor practice ( $\leq 25 \%)$} & \multicolumn{2}{|c|}{ Good practice (26-50\%) } & \multicolumn{2}{|c|}{ Very good practice (51-75\%) } & \multirow{2}{*}{$\begin{array}{c}\chi^{2} \\
\mathbf{p} \text { value }\end{array}$} \\
\hline & (f) & $\%$ & (f) & $\%$ & (f) & $\%$ & \\
\hline \multicolumn{7}{|l|}{ Personal habits } & \multirow{5}{*}{$\begin{aligned} \chi^{2} & =22.59 \\
p & =0.001\end{aligned}$} \\
\hline Smoking & 0 & 0 & 20 & 6.7 & 7 & 2.3 & \\
\hline Alcohol consumption & 0 & 0 & 16 & 5.3 & 3 & 1.0 & \\
\hline Tobacco chewing & 1 & 3.3 & 10 & 3.3 & 3 & 1.0 & \\
\hline No habits & 0 & 0 & 202 & 67.3 & 38 & 12.7 & \\
\hline
\end{tabular}

Table 4: Association of the level of practice regarding the preventive health behavior among hypertensive clients with their selected demographic variables.

\begin{tabular}{|c|c|c|c|c|c|c|c|}
\hline \multirow[t]{2}{*}{ Bio physiological variables } & \multicolumn{2}{|c|}{ Poor practice ( $\leq 25 \%)$} & \multicolumn{2}{|c|}{ Good practice (26-50\%) } & \multicolumn{2}{|c|}{ Very good practice $(51-75 \%)$} & \multirow{2}{*}{$\begin{array}{c}\chi^{2} \\
\mathrm{p} \text { value }\end{array}$} \\
\hline & (f) & $\%$ & (f) & $\%$ & (f) & $\%$ & \\
\hline \multicolumn{7}{|l|}{ Fasting blood sugar } & \multirow{4}{*}{$\begin{array}{c}\chi^{2}=12.88 \\
p=0.04\end{array}$} \\
\hline$<70 \mathrm{mg} / \mathrm{dL}$ & 1 & 0.3 & 18 & 6.0 & 6 & 2.0 & \\
\hline $70-99 \mathrm{mg} / \mathrm{dL}$ & 0 & 0 & 64 & 21.3 & 10 & 3.3 & \\
\hline $100-129 \mathrm{mg} / \mathrm{dL}$ & 0 & 0 & 119 & 39.7 & 24 & 8.0 & \\
\hline$\geq 130 \mathrm{mg} / \mathrm{dL}$ & 0 & 0 & 47 & 15.7 & 11 & 3.7 & \\
\hline \multicolumn{7}{|l|}{$\mathrm{HDL}(>45 \mathrm{mg} / \mathrm{dL})$} & \multirow{3}{*}{$\begin{array}{l}\chi^{2}=9.06 \\
p=0.01\end{array}$} \\
\hline$<45 \mathrm{mg} / \mathrm{dL}$ & 1 & 0.3 & 137 & 45.7 & 17 & 5.7 & \\
\hline$>45 \mathrm{mg} / \mathrm{dL}$ & 0 & 0 & 111 & 37.0 & 34 & 11.3 & \\
\hline \multicolumn{7}{|l|}{ Serum bicarbonate } & \multirow{3}{*}{$\begin{array}{l}\chi^{2}=5.97 \\
p=0.05\end{array}$} \\
\hline$<22 \mathrm{meq} / \mathrm{L}$ & 0 & 0 & 207 & 69.0 & 39 & 13.0 & \\
\hline$>29 \mathrm{meq} / \mathrm{L}$ & 1 & 0.3 & 41 & 13.7 & 12 & 4.0 & \\
\hline \multicolumn{7}{|l|}{ Duration of illness } & \multirow{5}{*}{$\begin{array}{c}\chi^{2}=13.44 \\
p=0.03\end{array}$} \\
\hline Less than 5 years & 0 & 0 & 87 & 29.0 & 17 & 5.7 & \\
\hline $5-10$ years & 1 & 0.3 & 121 & 40.3 & 19 & 6.3 & \\
\hline $11-15$ years & 0 & 0 & 11 & 3.7 & 9 & 3.0 & \\
\hline More than 15 years & 0 & 0 & 29 & 9.7 & 6 & 2.0 & \\
\hline
\end{tabular}

Table 5: Association of the level of practice regarding the preventive health behavior among hypertensive clients with their selected bio physiological variables. 
Citation: Lalou L, Sonia L, Venkatasan L (2018) Risk Factors and Preventive Health Behavior among Hypertensive Clients Attending Master Health Checkup at Selected Hospitals, in Different Geographic Areas. J Hypertens (Los Angel) 7: 256. doi: 10.4172/2167-1095.1000256

Page 4 of 6

Figure 3 depicts that, In Tamil Nadu (62.67\%) had moderately adequate knowledge and in Kerala (53.33\%) had adequate knowledge.

Figure 4 depicts that, most of the clients in Tamil Nadu (91.33\%) and majority of them in Kerala followed good practices (74\%) regarding preventive health behavior of hypertension.

Figure 5 depicts that, there was positive correlation between knowledge and practice regarding preventive health behavior in Tamil Nadu $\mathrm{r}=0.26$ significant at $\mathrm{p}<0.001$, whereas in Kerala $\mathrm{r}=0.28$ significant at $\mathrm{p}<0.01$, and overall $\mathrm{r}=0.33$ significant at $\mathrm{p}<0.001$.

\section{Discussion}

The study reveals that more than half of the clients in Kerala (52\%) and less than half of the clients in Tamil Nadu (39.33\%) were aged above 60 years. Majority of the clients in Tamil Nadu (64\%) and more than half of the clients in Kerala (52\%) were females. This skewed gender ratio is probably due to the gender specific risk factors. The findings were consistent with the study conducted by Pinto (2007) on blood pressure and ageing among 3500 persons over 64 years participated in the study suggest increased disease burden side effects and comorbidities with ageing require consideration when treating elderly to balance the risk and benefit [2]. However, at least those between the age group were of 40 years and above should focus attention on control of hypertension was indicated.

The study findings revealed the following distribution of risk factors among hypertensive clients. Occasional intake of salted snacks

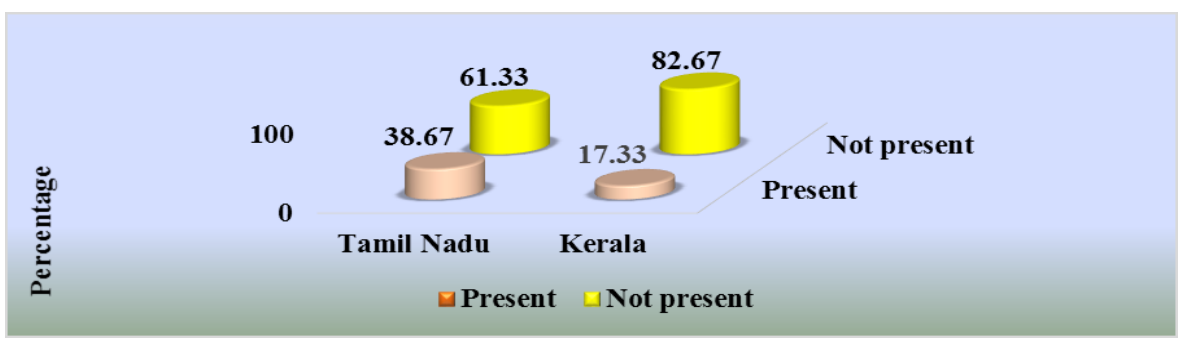

Figure 1: Percentage distribution of family history of obesity among hypertensive clients.

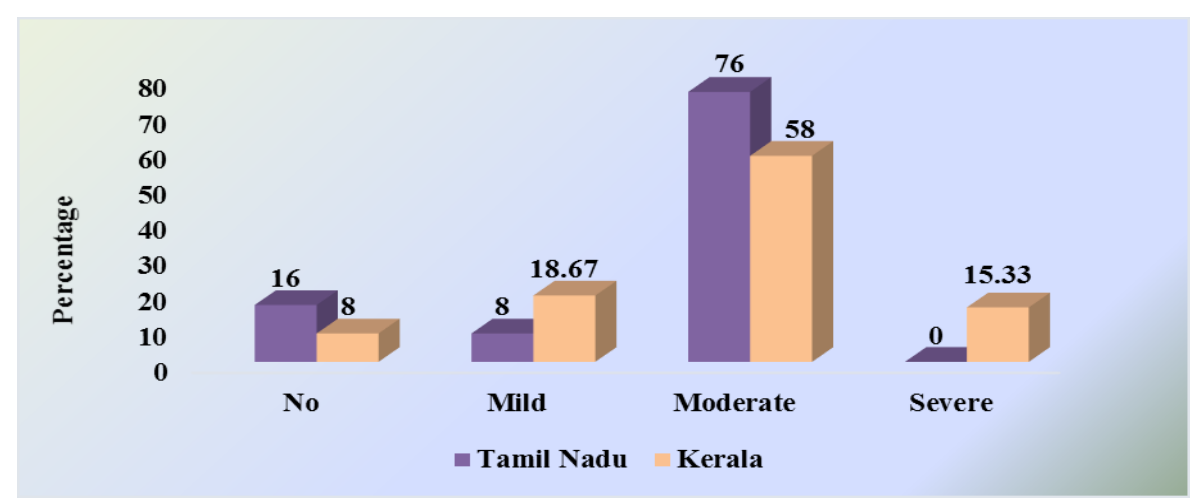

Figure 2: Percentage Distribution of Stress among Hypertensive Clients.

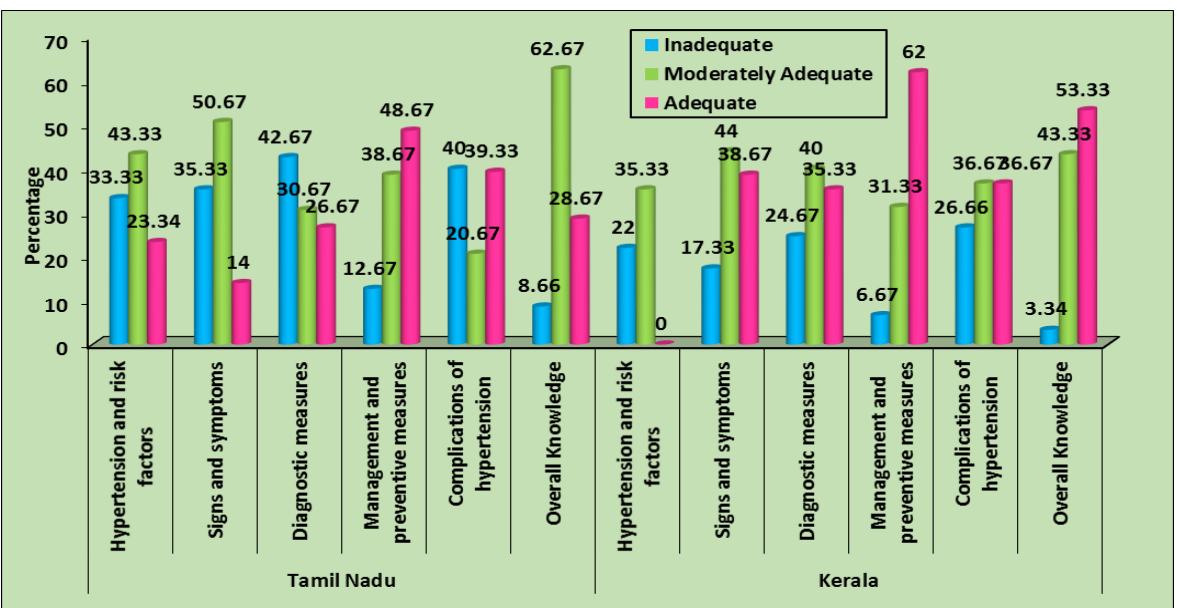

Figure 3: Frequency and Percentage Distribution of Level of Knowledge regarding the Preventive Health Behavior among Hypertensive Clients 


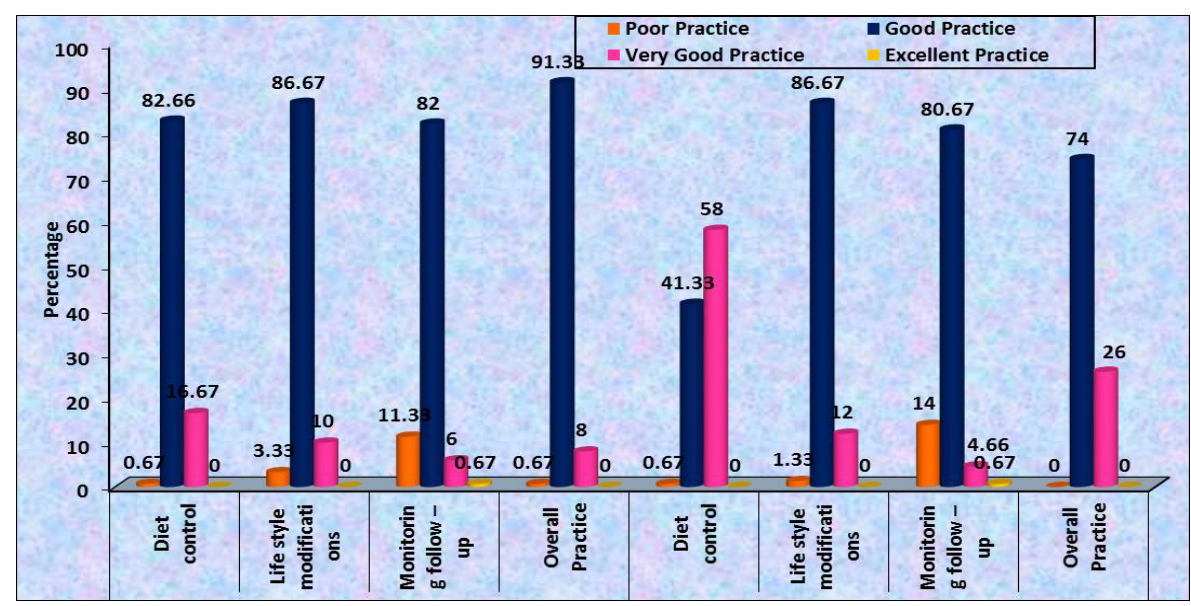

Figure 4: Frequency and Percentage Distribution of Level of Practice regarding the Preventive Health Behavior among Hypertensive Clients.
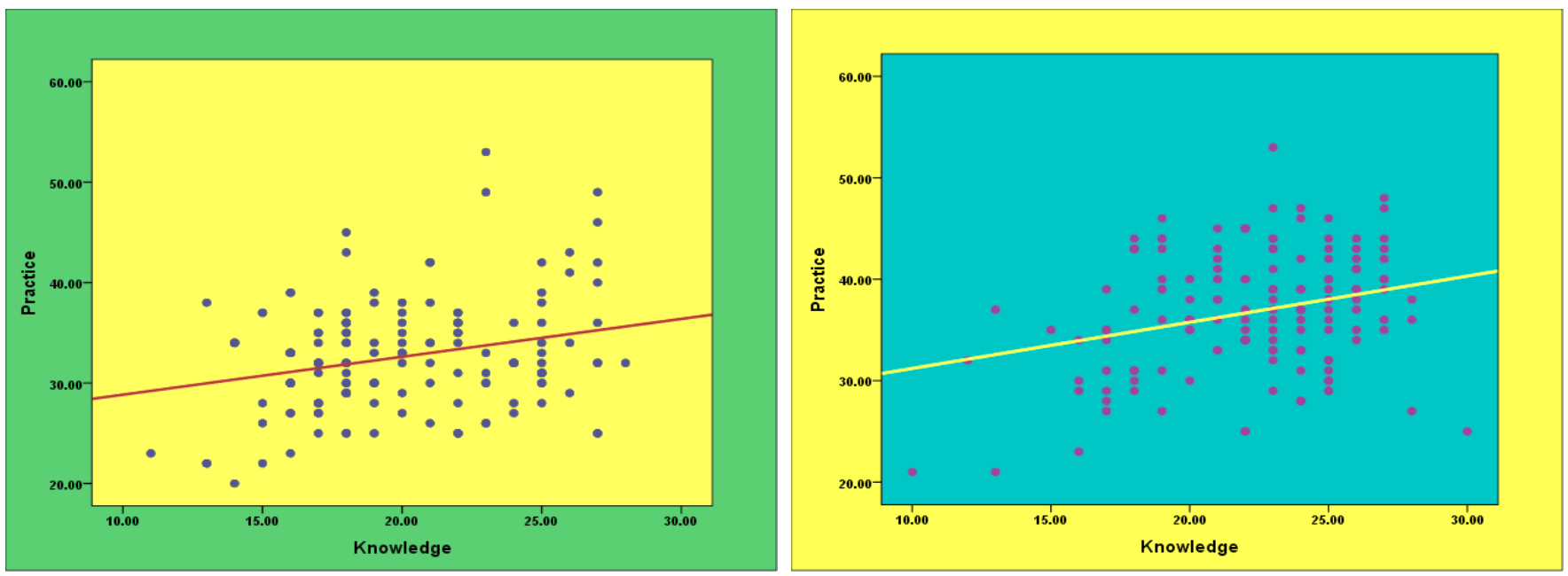

$p<0.001, p<0.01$

Figure 5: Correlation between Knowledge and Practice Regarding the Preventive Health Behavior among Hypertensive Clients in Tamil Nadu and Kerala

and fried foods $(35.33 \%, 32 \%)$, oily foods $(32 \%, 26.67 \%)$ was found to be the significant risk factors in Kerala and Tamil Nadu respectively. Majority of the clients in Tamil Nadu (86\%) and in Kerala (82\%) had daily intake of fruits and vegetables. This is congruent with the study conducted by Wang et al. (2012) to assess the fruits and vegetables intake is beneficial effect of a higher intake of fruits and vegetables as a part of healthy dietary pattern on hypertension prevention, possibly through improvement in body weight regulation $[3,4]$. The study shown that more than half of the clients in Kerala had adequate knowledge (53.33\%) whereas majority of them in Tamil Nadu had moderately adequate knowledge (62.67\%) regarding preventive health behavior of hypertension. The findings were compared with another cross sectional study by Sebastian et al. (2016) to assess the prevalence, control and knowledge of hypertension among 1154 adult participants in Kerala [3]. From the present study is that adequate knowledge is needed for better control and prevention of hypertension.

Most of the clients in Tamil Nadu (91.33\%) and majority of them in Kerala followed good practices (74\%) regarding preventive health behavior of hypertension. This is congruent with the study conducted by Flower and Prince (2017) identify to assess the knowledge and practice regarding hypertension and its association with the level of blood pressure among 100 hypertensive adults in Tamil Nadu [5]. The study findings revealed that majority $76 \%$ of the adults had moderately adequate knowledge and majority $78 \%$ of the adults had good practice. The mean score of knowledge and practice regarding hypertension was $18.45(\mathrm{SD} \pm 3.59)$ and $8.7(\mathrm{SD} \pm 2.09)$. There was a significant positive correlation between $(\mathrm{r}=0.4)$ of knowledge and practice regarding hypertension among hypertensive clients. However, knowledge and practice had an influence on hypertension among adults and good practice may help the individual to maintain normal blood pressure.

\section{Implications of the Study}

The findings of this study have significant implications for highlight the role of nurses in the prevention and early detection of risk factors and preventive health behavior of hypertension, which has implications on nursing practice, nursing administration and nursing research. By assessing the risk factors and preventive health behavior of hypertension can provide clear ideas of the various measures to be taken, to improve the quality of life of an individual. 
Citation: Lalou L, Sonia L, Venkatasan L (2018) Risk Factors and Preventive Health Behavior among Hypertensive Clients Attending Master Health Checkup at Selected Hospitals, in Different Geographic Areas. J Hypertens (Los Angel) 7: 256. doi: 10.4172/2167-1095.1000256

Page 6 of 6

\section{Limitations of the Study}

The limitations of this study are recognized by the researchers, First and foremost, the study was conducted in a private set up, and findings cannot be generalized to other settings. Second, the settings were selected based on the convenience of researcher. Third, the problem faced during the study was few patients refused to participate in the study and had problem in getting permission from hospitals in Kerala. Finally, three settings were included to conduct research, one in Chennai, one in Kerala and third in Andhra Pradesh. As permission was not granted in Andhra Pradesh, hence the study was restricted to only two settings at Tamil Nadu and Kerala.

\section{Conclusion}

Hypertension is one of the most common life style diseases today. The overall prevalence of hypertension in India was 30\%. The researcher concludes that to finding out the risk factors of hypertension and preventive health behavior among hypertensive clients in Tamil Nadu and Kerala helps assessment of the prevalence and people's perception regarding hypertension as manageable and nonlife threatening hypertension without facing any complications in future. However, a mass awareness programme is needed to educate the public in the adoption of a healthy life style in day today life in order to prevent the occurrence of these co morbidities of hypertension.

\section{Recommendations}

The study can be conducted on a large sample to generalize the results. A similar study can be conducted in different settings and another places to improve the knowledge and practice regarding preventive health behavior of hypertensive clients.

\section{Acknowledgement}

I thank God Almighty for showering his everlasting love and blessings upon me and guidance in the matters at hand and for clearly showing me the way to conduct my work with a spirit of joy and enthusiasm throughout my study and all those who have supported me in prayer and those who have helped me to successfully complete this study.

\section{Financial Support and Sponsorship}

Nil

\section{Conflicts of Interest}

There are no conflicts of interest.

\section{References}

1. World Health Organization (2016) World health statistics 2016: monitoring health for the SDGs sustainable development goals. World Health Organization.

2. Pinto E (2007) Blood pressure and ageing. Postgraduate Medical Journal 83 109-114.

3. Wang L, Manson JE, Gaziano JM, Buring JE, Sesso HD (2011) Fruit and vegetable intake and the risk of hypertension in middle-aged and older women. American Journal of Hypertension 25: 180-189.

4. Sebastian NM, Jesha MM, Haveri S, Nath A (2016) Hypertension in Kerala A study of prevalence, control, and knowledge among adults. International Journal of Medical Science and Public Health. 5: 2041-2046.

5. Flower PL, Prince VA (2017) Study to assess the Knowledge and Practice regarding Hypertension and its association with The level of Blood Pressure among adults in Nanchiyampalayam at Dharapuram with A View of Conducting an Awareness Programme. International Journal of Nursing Education and Research 5: 403-408. 